\title{
Proliferating cell nuclear antigen (PCNA) and nucleolar organiser regions in Hodgkin's disease: Correlation with morphology
}

\author{
J Freeman, D B Kellock, C C-W Yu, J Crocker, D A Levison, P A Hall
}

\begin{abstract}
Aim-To define the distribution of proliferating cell nuclear antigen (PCNA) and silver staining nucleolar organiser regions (AgNORs) in Hodgkin's disease.

Methods-PCNA was shown in a series of 34 cases of Hodgkin's disease using immunohistochemical methods. In a second series of 46 cases the AgNOR technique for interphase nucleolar organiser regions was studied. Both series comprised routinely fixed and processed paraffin wax sections of three main Rye subtypes.

Results-In all cases, regardless of Rye subtype, most Sternberg-Reed cells and mononuclear Hodgkin cells showed nuclear PCNA immunoreactivity and such cells had 15 or more AgNOR sites. The Hodgkin cells had, in general, about half the number of AgNORs seen in Sternberg-Reed variants.

Conclusions-These data support the notion that Hodgkin's disease can be regarded as a high grade lymphoma, the large Hodgkin's and Sternberg-Reed cells being the (PCNA positive and AgNOR rich) neoplastic elements with high proliferative capacity. A smaller proportion of the associated cells also showed evidence of proliferation.
\end{abstract}

(F Clin Pathol 1993;46:446-449)

Hodgkin's disease comprises a complex admixture of cells, the characteristic SternbergReed and Hodgkin cells, and other cell types including lymphocytes, eosinophils, and macrophages. Most authors now agree that the Sternberg-Reed cells and mononuclear variants make up the neoplastic component of this tumour, although the histogenesis of these cells remains obscure. The associated lymphoid and other cells have been viewed as a "reactive" component but the pathogenesis and true biological relevance of these also remain uncertain. The presence of this complex heterogeneous mixture of cell types has frustrated many attempts at analysing the nature of this tumour. In lymphomas other than Hodgkin's disease, the assessment of indices of cellular proliferation has proved a valuable indicator of biological characteristics, correlating with morphological classification $^{1-5}$, and providing prognostic information. ${ }^{6}$ But few studies of the assessment of cellular proliferation in Hodgkin's disease have been reported. One important reason for this has been the complex nature of this tumour in terms of its heterogeneous cellular composition.

Proliferating cell nuclear antigen (PCNA; also known as DNA polymerase $\delta$ auxiliary protein) is a 36 kilodalton nuclear protein expressed in cycling cells. ${ }^{7-10} \mathrm{~A}$ monoclonal antibody, PC10, has recently been described which recognises PCNA and which can be used to demonstrate the proliferative compartment of normal tissues. ${ }^{10}$ There is also a linear relation between the number of $\mathrm{Ki} 67$ staining cells in nodal non-Hodgkin's lymphomas and the number of cells staining with PC10. ${ }^{10}$ Similarly, in extranodal lymphomas there is a linear relation between PC10 staining and $S$ phase fraction, as assessed by flow cytometry. ${ }^{11}$ Consequently in normal tissues and in lymphomas PC10 immunostaining can be used as a marker of cell proliferation.

In 1987, Crocker and Nar described ${ }^{12}$ the application of a colloidal silver method ${ }^{13}$ for the demonstration of nucleolar organiser regions (AgNORs) in histological sections. This method, which was originally used by cytogeneticists for the detection of acrocentric chromosomes, has since been used in a wide range of histopathological settings. ${ }^{14}$ The exact nature of nucleolar organiser regions remains uncertain and the relation of their number (or size) to variables of cell proliferation the subject of some debate. It has been suggested that the association of nucleolar organiser regions with acrocentric chromosomes may allow nucleolar organiser region staining to be used as an indicator of ploidy. ${ }^{15-17}$ It has also been argued that an assessment of nucleolar organiser region number may reflect cellular activity and possibly proliferation, ${ }^{18-20}$ and recent studies indicate that in lymphomas the number of nucleolar organiser regions is closely related to cellular proliferation. ${ }^{21}{ }^{22}$ There is also now direct evidence that interphase AgNOR numbers are not related to ploidy, ${ }^{23}$ at least in lymphoid cells, although observations from trophoblastic tissue contradict this. ${ }^{17}$

The purpose of the present study was first, to define the number and distribution of PCNA immunoreactive cells in Hodgkin's disease; second, to define the phenotype of PCNA immunoreactive cells; and third, to assess the number and distribution of AgNORs.

\section{Methods}

PCNA immunoreactivity was assessed in a series of 34 cases of Hodgkin's disease,

\author{
Correspondence to: \\ Accepted for publication \\ 21 October 1992 \\ Department of \\ United Medical and \\ Dental Schools, \\ St Thomas's Campus
}


Table 1 Percentages of PCNA immunoreactive cells in Hodgkin's disease

\begin{tabular}{llll}
\hline & $\begin{array}{l}\text { Mixed cellularity } \\
(n=15)\end{array}$ & $\begin{array}{l}\text { Nodular sclerosing } \\
(n=15)\end{array}$ & $\begin{array}{l}\text { Lymphocyte depleted } \\
(n=4)\end{array}$ \\
\hline Sternberg-Reed & $\begin{array}{l}84 \cdot 2 \text { range } 73-96 \\
\text { cells }\end{array}$ & $\begin{array}{l}87 \cdot 0 \text { range } 81-98 \\
(8 \cdot 3)\end{array}$ & $\begin{array}{l}91 \cdot 1 \text { range } 74-100 \\
(2 \cdot 8)\end{array}$ \\
Mononuclear & $\begin{array}{l}75 \cdot 3 \text { range 53-89 } \\
\text { Hodgkin cells }\end{array}$ & $\begin{array}{l}77 \cdot 5 \text { range 60-93 } \\
(10 \cdot 0)\end{array}$ & $\begin{array}{l}80 \cdot 0 \text { range 56-92 } \\
(12 \cdot 0)\end{array}$ \\
$\begin{aligned}(8 \cdot 4) \\
\text { Other lymphoid }\end{aligned}$ & $\begin{array}{l}12 \cdot 2 \text { range 3-24 } \\
\text { cells }\end{array}$ & $\begin{array}{l}12 \cdot 5 \text { range 2-22 } \\
(8 \cdot 0)\end{array}$ & $\begin{array}{l}9 \cdot 5 \text { range 3-21 } \\
(5 \cdot 0)\end{array}$ \\
\hline
\end{tabular}

Figures in parentheses are standard errors; ( $t$ test; $p=N S$ ).

including: 15 nodular sclerosing, 15 mixed cellularity, and four cases of lymphocyte depletion. All had been diagnosed on the basis of typical histological and clinical features supported by immunophenotypic studies. $^{24}$

In a second series of 46 cases of Hodgkin's disease nucleolar organiser regions were quantitated. Twenty of these cases were included in the first series stained for PCNA. This series included mixed cellularity $(\mathrm{n}=$ $19)$, nodular sclerosing $(n=21)$, and lymphocyte depleted $(n=6)$.

\section{PROLIFERATING CELL NUCLEAR ANTIGEN STAINING}

The murine monoclonal antibody PC10 was used as described previously. ${ }^{910}$ Primary antibody was used at a dilution of 1 in 100 with overnight incubation at room temperature and detected using an avidin-biotin complex immunoperoxidase method (Dakopatts UK Ltd) with diaminobenzidine as substrate. A light haematoxylin counterstain was used. PCNA immunoreactivity is identified as diffuse or granular nuclear staining and any such staining in a nucleus is regarded as positive. Histological sections stained for PCNA were assessed both qualitatively and in a detailed quantitative manner, with counts of Sternberg-Reed cells, mononuclear Hodgkin cells, and associated lymphoid cells. A minimum of 1000 cells were assessed in each case.

NUCLEOLAR ORGANISER REGION STAINING

Paraffin wax sections $(3 \mu \mathrm{m})$ were cut, dewaxed in xylene, and hydrated through graded ethanols to deionised water. The nucleolar organiser region staining solution was prepared as described before ${ }^{12}$ and poured over the sections where it was left for 30 minutes at room temperature in the dark. The silver colloid was then washed off with deionised water, the sections taken to xylene and mounted in DPX. No counterstain was used.

Table 2 Mean numbers of silver staining nucleolar organiser regions seen in nuclei of cells in cases of Hodgkin's disease

\begin{tabular}{|c|c|c|c|}
\hline & $\begin{array}{l}\text { Mixed cellularity } \\
(n=19)\end{array}$ & $\begin{array}{l}\text { Nodular sclerosing } \\
(n=21)\end{array}$ & $\begin{array}{l}\text { Lymphocyte depleted } \\
(n=6)\end{array}$ \\
\hline Sternberg-Reed & 16.9 range $12-21$ & $15 \cdot 3$ range $13-19$ & $17 \cdot 1$ range $13-21$ \\
\hline Mononuclear & $10 \cdot 1$ range $6-15$ & $\begin{array}{l}7.5 \text { range } 5-4 \\
(0.9)\end{array}$ & $\begin{array}{l}8.4 \text { range } 6-16 \\
(1.4)\end{array}$ \\
\hline Other lymphoid & 1.9 range $1-3$ & $2 \cdot 1$ range $1-3$ & 1.9 range $1-3$ \\
\hline
\end{tabular}

Figures in parentheses are standard errors; ( $t$ test; $p=N S$ ).
COUNTS OF NUCLEOLAR ORGANISER REGIONS Colloidal silver stained sections were examined by one observer (PAH) using a $\times 100$ oil-immersion objective. The number of nucleolar organiser regions in a minimum of 500 cells, in fields selected by the use of a random number table, were counted and a mean score determined for each case. The number of nucleolar organiser regions present within Sternberg-Reed cells, mononuclear Hodgkin cells, and other cell types were also independently recorded and the mean value calculated. Structures such as high endothelial venules were not counted. Ten cases were included in the series twice to assess the reproducibility of scoring of nucleolar organiser regions.

\section{Results}

PCNA IMMUNOSTAINING

Nuclear PCNA immunoreactivity was present in most of the Sternberg-Reed cells (range 73-100\%) and most mononuclear Hodgkin cells (range 53-93\%) in examples of all three types of Hodgkin's disease (table 1). Interobserver variation in assessing the proportion of stained cells was less than $5 \%$. Cytoplasmic immunoreactivity was also frequently seen in Sternberg-Reed cells. Nuclear PCNA immunoreactivity was also present in a variable proportion of admixed lymphoid cells.

NUCLEOLAR ORGANISER REGIONS

Using the colloidal silver method for nucleolar organiser regions, a variable number of clearly defined "dots" or "blebs" were present in all nuclei. Careful focusing was necessary to identify all such dots in a nucleus. The results are presented in table 2. A large number of silver stained dots were observed, typically 15 or more, within the nuclei of Sternberg-Reed cells. Most AgNORs were arranged at the periphery of the nucleus, and several AgNORs were present within the nucleoli. In mononuclear Hodgkin cells a similar spatial distribution of AgNOR staining was seen, typically with seven to 10 AgNORs present. Other cell types contained only one to four AgNORs. The mean number of AgNORs in each case was difficult to interpret because of the variable proportions of the different subpopulations present.

Of more importance were the numbers of AgNORs seen in differing subpopulations of cells within cases of Hodgkin's disease. The results in table 2 indicate that the mean number of AgNORs seen in Sternberg-Reed cells was very similar irrespective of histological subtype of Hodgkin's disease. Similarly, the mononuclear Hodgkin cells had similar numbers of AgNORs in each of the histological subtypes. The number of AgNORs seen in replicate sections counted at different times by the same observer indicate that the method is reproducible with a variation of less than $11 \%$, indicating close concordance. Table 2 shows that the number of AgNORs present in mononuclear forms of Hodgkin 
cells is roughly $50 \%$ of that seen in SternbergReed cells, and consistent with a derivation of Sternberg-Reed cells from mononuclear variants by fusion or endomitotic duplication.

\section{Discussion}

Cellular proliferation in Hodgkin's disease has been investigated before in several ways. Early studies used autoradiography to demonstrate thymidine incorporation during DNA synthesis. Such studies suggested that Sternberg-Reed and Hodgkin's cells were not actively proliferating, but the difficulty of assigning cells to cytological categories hindered interpretation. ${ }^{25} 26$ The DNA content of cells in Hodgkin's disease has been investigated using both static ${ }^{27}$ and flow cytometry. ${ }^{28} 29$ Morgan et al have reported that the assessment of ploidy and proliferative fraction was of no prognostic value in a retrospective series of 115 cases. ${ }^{29}$ This is hardly surprising given the cytological heterogeneity of Hodgkin's disease and the existence of considerable heterogeneity of ploidy within Sternberg-Reed cells. ${ }^{28}{ }^{29}$ Meaningful data with regard to cellular proliferation require the application of methodologies that allow heterogeneous cellular populations to be identified. In this study the in situ identification of characteristic cellular morphology allowed the proliferative activity of relevant populations to be assessed with regard to expression of PCNA and of nucleolar organiser region staining.

Immunohistological methods for the assessment of cellular proliferation in Hodgkin's disease have recently been reported. Gerdes et al used CD30 immunoreactivity to demonstrate Sternberg-Reed and mononuclear Hodgkin cells in cryostat sections of Hodgkin's disease and cryostat sections double stained with $\mathrm{Ki} 67$ to demonstrate proliferating cells. ${ }^{30}$ Falini et al used similar methods on cytological preparations. ${ }^{31}$ These studies suggest that most putative neoplastic cells were proliferating. The results of our study support these data and indicate that in Hodgkin's disease most neoplastic cells are proliferating. In one respect these data are surprising: mitotic figures are remarkably rare in Sternberg-Reed cells, although they can be found in mononuclear forms (PAH and DAL, personal observations). How can the paucity of mitoses and labelling with thymidine be reconciled with abundant $\mathrm{Ki67}$ and PCNA immunoreactivity and the presence of many AgNORs? One possible explanation is that Sternberg-Reed cells are cycling, but slowly. Indeed, they could be arrested, at least to some extent, in cycle and thus express proliferation associated antigens, but they do not take up thymidine or progress into mitosis. Such an interpretation again highlights the important difference between state and rate of proliferation. ${ }^{32}{ }^{33}$ This interpretation might also be a partial explanation for the presence of cytoplasmic PCNA immunoreactivity, ${ }^{34}$ because slowed or arrested cells might continue to make PCNA.
The data presented here indicate that PCNA expression occurs in a proportion of the associated lymphoid cells present in Hodgkin's disease, suggesting that they are actively proliferating. This indicates that the assessment of cellular proliferation, by whatever method, in lymphoma and other tumours must involve consideration of the cellular heterogeneity within the neoplasm. ${ }^{32} 33$ Further studies will be required to determine the possible clinical relevance of cellular proliferation in these cell populations. The true importance of AgNOR staining may remain uncertain, but it is clear that the assessment of PCNA immunoreactivity is more easily performed.

Finally, the results of this study support the notion that Hodgkin's disease can be regarded as a high grade lymphoma with a large admixed population of additional lymphoid cells, because (a) in all histological subtypes most (more than $80 \%$ ) putative neoplastic cells, as judged by morphology, show PCNA immunoreactivity; and (b) the putative neoplastic cells contain large numbers of nucleolar organiser regions. These data make the response of Hodgkin's disease to contemporary combination chemotherapy ${ }^{35}$ more understandable, because tumours with a high proliferative fraction will be more amenable to cytotoxic agents. ${ }^{6}$

Furthermore, the proposition that the ReedSternberg and mononuclear Hodgkin cells have a relatively long cell cycle time is consistent with the requirement for multiple courses of treatment, and with mathematical models of treatment in Hodgkin's disease. ${ }^{36}$ The clinical relevance of assessing PCNA immunoreactivity in Hodgkin's disease deserves prospective analysis.

\section{Addendum}

Since this paper was written evidence has emerged to suggest that PCNA "overexpression" is associated with DNA repair as well as proliferation. The finding of high Ki67 indices in Sternberg-Reed and mononuclear Hodgkin's cells, ${ }^{30}$ the correlation in our study between PCNA index and AgNOR index, and previous demonstration of correlations between PCNA index and other indices of cell proliferation in non-Hodgkin's lymphomas, however, ${ }^{1011}$ are all consistent with Reed-Sternberg and mononuclear Hodgkin's cells being cycling cells. We consider that the points made in the discussion are still valid.

1 Akerman M, Brandt L, Johnson A, Olson H. Mitotic activity in non-Hodgkin's lymphoma. Relation to the Kiel classification and to prognosis. $\mathrm{Br} f$ Cancer 1987;55:219-23.

2 Diamond LW, Nathwani BN, Rappaport H. Flow cytometry in the diagnosis and classification of malignant lymphoma and leukaemia. Cancer 1982;50:1122-35.

3 Gerdes J, Dallenbach F, Lennert K, Stein H. Growth fractions in malignant non-Hodgkin's lymphomas as fractions in malignant non-Hodgkin's lymphomas as
determined in situ with the monoclonal antibody Ki67. determined in situ with the monoc

4 Kvaloy S, Morton PF, Kaalhus O, Hoie J, FossAbrahamsen A, Godal T. ${ }^{3} \mathrm{H}$ thymidine uptake in B cell lymphomas: relationship to treatment response and survival. Scand $\mathcal{f}$ Haematol 1985;34:429-35. 
5 Silvestrini R, Piazza R, Riccardi A, Rilke F. Correlation of kinetic findings with morphology of non-Hodgkin's lymphomas. INCI 1977;58:499-504.

6 Hall PA, Gregory W, Richards MA, D'Ardenne AJ, Lister TA, Stansfeld AG. The prognostic significance of Ki67 immunostaining in non-Hodgkin's lymphoma. $\mathcal{F}$ Pathol 1988;154:223-35.

7 Bravo R, MacDonald-Bravo H. Existence of two populations of cyclin/proliferating cell nuclear antigen during the cell cycle: association with DNA replication sites. $f$ Cell Biol 187;105:1549-54.

8 Fairman MP. DNA polymerase/PCNA: actions and interactions. F Cell Sci 1990;94:1-4.

9 Waseem N, Lane DP. Monoclonal antibody analysis of the proliferating cell nuclear antigen (PCNA) Structural observations and the detection of a nuclear form. 7 Cell Sci 1990;96:121-9.

10 Hall PA, Levison DA, Woods AL, et al. Proliferating cell nuclear antigen immunolocalisation in paraffin sections. An index of cellular proliferation with evidence of An index of cellular proliferation with evidence of deregulated expressi

11 Woods AL, Hanby AM, Hall PA, Shepherd NA, Waseem N, Lane DP, Levison DA. The prognostic value of PCNA (proliferating cell nuclear antigen) immunostaining in gastro-intestinal lymphoma. Histopathology 1991;19:21-8.

12 Crocker J, Nar P. Nucleolar organiser regions in lymphomas. F Pathol 1987;151:111-8.

13 Howell WM, Black DA. Controlled silver staining of nucleolar organiser regions with a protective colloidal developer: a one step method. Experentia 1980;36:1014.

14 Crocker J. Nucleolar organiser regions. In: Pathology of the nucleus. Current topics in pathology. Berlin Springer Verlag, 1989: 91-149.

15 Hubbell HR, Hsu TC. Identification of nucleolar organiser regions (NOR's) in normal and neoplastic cells by the silver staining technique. Cytogenet Cell Genet 1977;19:185-96.

16 Kohno S, Abe S, Matsui S, Sandberg AA. Chromosome and causation of human cancer and leukaemia. XXXVII. Nucleolus organisers on the Ph' chromosome in chronic myeloid leukaemia. Cancer Genet Cytogenet 1979;1:15-20.

17 Suresh UR, Chaucer L, Buckley CH, Fox H. Do AgNOR counts reflect cellular ploidy or cellular proliferation? A study of trophoblastic tissue. F Pathol 1990;160:213-17.

18 Ploton D, Menager M, Jeannesson P, Himber G, Pigeon $F$, Adnett JJ. Improvement in the staining and in the visualisation of the argyrophilic proteins of the nucleolar visualisation of the argyrophilic proteins of the nucleolar
organiser region at the optical level. Histochem $f$ organiser region

19 Reeves BR, Casey G, Harris H. Variation in the activity of nucleolar organisers in different tissues, demonstrated by silver staining of human normal and leukaemic cells. Cancer Genet Cytogenet 1982;6:223-30

20 Derenzini M, Pession A, Farabegoli F, Badiali M, Dehan P. Relationship between interphasic nucleolar organiser regions and growth rate in two neuroblastoma cell lines.
Am f Pathol 1989;134:925-32.

21 Hall PA, Crocker J, Watts A, Stansfeld AG. A comparison of Ki67 immunostaining and nucleolar organiser region staining in non-Hodgkin's lymphoma. Histopathology 1988;12:373-81.

22 Crocker J, MaCartney JC, Smith PJ. Correlation between DNA flow cytometric and nucleolar organiser region data in non-Hodgkin's lymphoma. I Pathol 1988; 154:151-6.

23 Jan-Mohamed R, Armstrong S, Crocker J, Leyland MJ, Huten $M$. The relationship between number of interphase NORs and NOR-bearing chromosomes in nonHodgkin's lymphoma. $\mathcal{F}$ Pathol 1989;158:3-7.

24 Hall PA, D'Ardenne AJ, Stansfeld AG. Paraffin section immunohistochemistry. II Hodgkin's disease and large cell anaplastic (Kil) lymphoma. Histopathology 1988; 13:161-70.

25 Cooper EH, Peckham MJ, Millard RE, Hamlin IME Gerard Marchant R. Cell proliferation in human malignant lymphomas. Analysis of labelling index and DNA content in cell populations obtained by biopsy. Eur $\mathcal{f}$ content in cell popula

26 Peckham MJ, Cooper EH. Proliferation characteristics of the varying classes of cells in Hodgkin's disease. Cance 1969;24:135-46.

27 Petrakis NL, Bostick WL, Siegel BV. The deoxyribonucleic acid (DNA) content of Sternberg-Reed cells of Hodgkin's disease. fNCI 1959;22:551-4

28 Anastasi J, Bauer KD, Variakojis D. DNA aneuploidy in Hodgkin's disease. A multiparameter flow-cytometric analysis with cytologic correlation. Am $\mathcal{f}$ Pathol 1987;128:573-82.

29 Morgan KG, Quirke P, O'Brien CI, Bird CC. Hodgkin's disease: a flow cytometric study. $f$ Clin Pathol 1988;41:365-9.

30 Gerdes J, Van Baarlen J, Pileri S, Schwarting R, Van Unnik JAM, Stein $H$. Tumour cell growth fraction in Hodgkin's disease. Am $\mathcal{F}$ Pathol 1987;128:390-3.

31 Falini B, Stein H, Pileri S, et al. Expression of lymphoidassociated antigens in Hodgkin's and Reed-Sternber cells of Hodgkin's disease. An immunocytochemical study of lymph node cytospins using monoclonal antibodies. Histopathology 1987;11:1229-42.

32 Hall PA, Levison DA. Assessment of cellular proliferation in histological material 7 Clin Pathol 1990;43:184-92.

33 Hall PA, Levison DA, Wright NA, eds. Assessment of cell proliferation in clinical practice. London: Springer Verlag, 1992.

34 Benjamin DR. Gown AM. Aberrant cytoplasmic expression of proliferating cell nuclear antigen in Hodgkin's disease. Am $¥$ Surg Pathol 1991;115:764-8.

35 Rosenberg SA. Hodgkin's disease. In: Calabreshi $P$ Schein PS, Rosenberg SA, eds. Medical oncology: Basic principles and clinical management of cancer. New York MacMillan, 1985:457-75.

36 Gregory WM. Mathematical modelling of cancer cell growth. In: Hall PA, Levison DA, Wright NA, Eds. Assessment of cell proliferation in clinical practice. London: Springer Verlag, 1992:197-202. 